\title{
Article \\ Addressing Religion in Secular Healthcare: Existential Communication and the Post-Secular Negotiation
}

\author{
Ricko Damberg Nissen ${ }^{1, *(1)}$ and Aida Hougaard Andersen ${ }^{2}(\mathbb{B}$ \\ 1 Research Unit of General Practice, University of Southern Denmark, 5000 Odense, Denmark \\ 2 Department of Psychology, University of Southern Denmark, 5230 Odense, Denmark; \\ ahandersen@health.sdu.dk \\ * Correspondence: rnissen@health.sdu.dk
}

Citation: Nissen, Ricko Damberg, and Aida Hougaard Andersen. 2022. Addressing Religion in Secular Healthcare: Existential

Communication and the Post-Secular Negotiation. Religions 13: 34 https://doi.org/10.3390/ rel13010034

Academic Editor: Joseph Rivera

Received: 16 November 2021

Accepted: 23 December 2021

Published: 30 December 2021

Publisher's Note: MDPI stays neutral with regard to jurisdictional claims in published maps and institutional affiliations.

Copyright: (C) 2021 by the authors. Licensee MDPI, Basel, Switzerland. This article is an open access article distributed under the terms and conditions of the Creative Commons Attribution (CC BY) license (https:// creativecommons.org/licenses/by/ $4.0 /)$.

\begin{abstract}
This article aims to understand why religion has proven difficult to address in secular healthcare, although existential communication is important for patients' health and wellbeing. Two qualitative data samples exploring existential communication in secular healthcare were analyzed following Interpretative Phenomenological Analysis, leading to the development of the analytical constructs of 'the secular' and 'the non-secular'. The differentiation of the secular and the nonsecular as different spheres for the individual to be situated in offers a nuanced understanding of the physician-patient meeting, with implications for existential communication. We conceptualize the post-secular negotiation as the attempt to address the non-secular through secular activities in healthcare. Employment of the post-secular negotiation enables an approach to existential communication where the non-secular, including religion, can be addressed as part of the patients' life without compromising the professional grounding in secular healthcare. The post-secular negotiation presents potential for further research, clinical practice, and for the benefit of patients.
\end{abstract}

Keywords: religion; secular; post-secular; existential communication; healthcare; qualitative methodology

\section{Introduction}

Religion has proven difficult in addressing the existential communication in Western secular healthcare, although research has found it important for patients' health and wellbeing (Brémault-Phillips et al. 2015; Dillard et al. 2021; Koenig et al. 2012). A reason for this difficulty can be located in the historical relation between religion and healthcare, namely in the privatization of religion that followed the secularization of societal discourses such as healthcare. Scandinavian countries are often defined as highly secular countries, creating a view of the inhabitants as holding primarily secular values and approaches to the existential dimensions of life (Zuckerman 2008). In opposition to this view, however, studies of Scandinavians show a more complex picture of the relationship among secular, spiritual, and religious values, and ways to make meaning in life (la Cour and Hvidt 2010; DeMarinis 2008; Sørensen et al. 2019).

Religion can be, and has been, defined in a multitude of ways. In this article, we take a social constructionist approach, and understand religion to be dependent on specific cultural and social contexts (Beckford 2003) as beliefs, experiences, and practices developed over time within a community and perceived to have a sacred character in relation to any form of transcendence (Koenig et al. 2012; Pargament et al. 2017).

Before the secularization, religion was an integrated and defining aspect of the societal discourses such as law, economics, education, and health. Through modernization and the Enlightenment heritage, the societal discourses were secularized, the influence of religion decreased and, from then, was only practiced officially in the formal settings of institutionalized religion or privately (Berger 2015; Eder and Bosetti 2006; Taylor 2007). According to the theory of secularization, the advance of modernity and progress would inevitably 
lead to the demise and eventual disappearance of religion, and humanity would outgrow religious beliefs as the processes of secularization unfurled (Berger 1999; Granqvist 2020; Stark 1999). Something different happened, however, and religion did not go gentle into that good night (Thomas 2017). During the last decades, the theory of secularization has come under pressure and needs reformulation (Berger 1999; Stark 1999; Stolz 2020) in order to encompass the pluralist character of the world and the growing presence of religion in the public sphere (Beaumont et al. 2020; Berger 2014).

The development of the global context and the relationship between religion and secularization is extremely complex, and secularization is not a homogeneous or universal process (Köhrsen 2012), which is also addressed in relating conceptualizations such as multiple modernities (Eisenstadt 2000), late-secularity (Possamai 2017), multiple secularities (Wohlrab-Sahr and Burchardt 2012), and the post-secular (Habermas 2008). The postsecular is an emerging academic concept that addresses the critique of the secularization theory at both the societal and individual level (Beaumont et al. 2020; Breemer et al. 2014; Eder and Bosetti 2006; Gorski et al. 2012; Habermas 2008; Nynäs et al. 2021), and it captures the understanding that there is a need for local contexts to address the continued presence of religion in secular societal discourses. The philosopher and sociologist Jürgen Habermas, one of the early ambassadors of the concept, based this argument on mainly two perspectives, namely that religion is gaining influence in national and international public spheres, and the continuing cultural entwinement of the world (Habermas 2008). The post-secular is documenting this renewed interest in religion across the secular societal discourses, not least across university departments, where religion have been treated with renewed intensity from various perspectives (Gorski et al. 2012; Hodkinson and Horstkotte 2020; Nynäs et al. 2021).

In healthcare, the post-secular can be argued as the renewed focus on the relationship between religion and health, exemplified in the handbook of Koenig et al. (2012), where the authors review nearly double the number of research studies about the relationship between religion and health than in the previous edition (Koenig et al. 2001).

Communication about religion, spirituality, and existential issues in healthcare has received great attention, and research has shown that approaching religious, spiritual, and existential themes in healthcare is difficult (Agledahl et al. 2011; Anandarajah et al. 2021; Andersen et al. 2019a; Assing Hvidt et al. 2017; Best et al. 2016; Carr 2010; Gulbrandsen et al. 2016; Nissen et al. 2019b). On the one hand, healthcare professionals have become aware of the possible importance of spirituality and religion for patient health (Kørup et al. 2021; Puchalski et al. 2014; Sloan et al. 1999), but, on the other, they find it difficult to incorporate religious coping, resources, needs, and distress into care and into doctor-patient communication in daily clinical interaction (Andersen et al. 2020; BrémaultPhillips et al. 2015; Dillard et al. 2021; Søberg et al. 2018). Furthermore, research has shown that patients often want these aspects incorporated in their communication with healthcare professionals but also that the patients themselves find it difficult (Andersen et al. 2021; Best et al. 2015; Perrin et al. 2021; Tarbi et al. 2021).

Existential communication is defined as communication about the different approaches to the existential dimensions including spiritual and religious approaches (Andersen et al. 2019a, 2019b). In our research, we focused on existential communication between patient and healthcare professionals, with a specific focus on religion (Andersen 2020; Nissen 2019). We identified a line of reasoning that reflected reasons why religion seemed so difficult to bring into the existential communication in a healthcare setting. Across our studies, the informants regarded religion as an issue too private to address in consultation. This was conceptualized as 'the privacy of religion argument' (Nissen 2019) and supports the above-mentioned findings that religion and existential issues are difficult to approach in healthcare. However, unresolved questions remain regarding a deeper understanding of why religion is found to be too private to be addressed, and whether and how these difficulties can be overcome in healthcare practice. 
The aim of this article is thus to study why religion is difficult to address in secular healthcare and whether the analytical constructs of 'the secular' and 'the non-secular' can deepen our understanding of and approach to existential communication.

The potential implications for healthcare, daily clinical practice, and further research is then be discussed in relation to the thematic finding of the post-secular negotiation.

\section{The Analytical Constructs}

Theoretically, we are inspired by the work of Peter L. Berger (Berger 2015; Berger and Luckmann 2016). We conceptualize spheres of relevance as the ability of the individual to determine the appropriate and relevant frame of mind and course of action in any given contextual situation. The two focal spheres of this study are 'the secular' and 'the non-secular'.

We use the secular in the understanding of "not connected with religious or spiritual matters" (Oxford Dictionary), and from two perspectives: 'secular societal discourses' and 'secular activities'. Secular societal discourses encapsulate the secularized institutions in society such as law, economics, education, health, etc. Secular activities contain activities of the individual relating to mundane activities in everyday life.

The understanding of the secular we oppose with the concept the non-secular. The non-secular contains discourses and activities that are oriented towards that which lies outside the secular activities of everyday life, such as the existential, spiritual, and religious dimensions of human life. A non-secular discourse could thus be exemplified by institutionalized religion. However, here, we are primarily concerned with the individual activities of the human being. At the individual level, this distinction between the secular and the non-secular implies that it is not the person who is secular, but the activity, because the concepts refer to the nature of the specific activities an individual engages in. Although this binary opposition of the secular and the non-secular is a simplification of the complex interaction between the two, we employ these constructs because they reflect the analytical findings in the data. Furthermore, positioning the secular and the non-secular as two different spheres with related activities highlights that people move and differentiate between these two spheres according to context and relevance, offering a nuanced understanding of the inhabitants of the secular countries. The heart surgeon, for example, who is about to perform surgery and who is, in this example, a religious person, knows that, for the duration of performing heart surgery, they are undertaking a secular activity in a secular societal discourse, and that they are not about to pause midway through the operation to recite an appropriate religious text (Berger 2015).

Furthermore, the distinction between the secular and the non-secular enables an understanding in which the non-secular can contain the many diverse approaches to the existential dimensions of human life, be they religious, spiritual, agnostic, atheistic, or any other approach. This distinction promotes the understanding that neither the secular nor the non-secular are fixed categories. This is an aspect that may contribute to existential communication in secular healthcare.

In sum, the analytical constructs entertained are:

The secular: discourses and activities in the secular sphere.

The non-secular: discourses and activities in the non-secular sphere.

\section{Materials and Methods}

The methodological approach is grounded in a hermeneutic-phenomenological tradition and bears the influence of the theoretical understanding outlined above. The analytical process was inspired by the phenomenological and hermeneutic approaches from Interpretative Phenomenological Analysis (Smith et al. 2009) and the iterative and explorative approach of Johannesen (2018). 


\subsection{The Background Studies}

The two studies leading to this article were focused on physician-patient communication in relation to the existential, spiritual, and religious concepts. The studies took place in 2016-2020 in the region of Southern Denmark. Both studies used qualitative methods and were based on semi-structured interviews with certified physicians in the medical specialties: psychiatry, chronic pain, and multiple sclerosis. Consequently, patients in this study refer to patients suffering from psychiatric illness, chronic pain, or multiple sclerosis, and the healthcare settings are psychiatry, chronic pain, and neurology. The aim of Andersen (2020) was to deepen the understanding of physicians' experiences with patients' illness-related existential, spiritual, and religious needs, and how the physicians addressed these needs (Andersen 2020). The aim of Nissen (2019) was to investigate what characterizes the approach of psychiatrists in Danish clinical practice regarding topics of a religious or spiritual nature (Nissen 2019).

The interviews were digitally recorded, pseudo anonymized, transcribed, and stored together with the interviewers' fieldnotes in a password-protected server at the authors university. The physicians gave written, informed consent before participating and received no monetary compensation. The original studies were assessed for review by the regional ethical scientific committee and exempted from the obligation to notify. The research was conducted according to the WMA Declaration of Helsinki.

The studies are further described in other articles, please see (Andersen et al. 2021; Andersen et al. 2020; Andersen et al. 2019b; Damberg Nissen et al. 2018; Nissen et al. 2019a, 2019b).

\subsection{Data Construction and Research Question}

The data material is based on a re-coding of the interviews $(n=30)$ of the outlined background studies based on an original research question for the present study: What characterizes the informants' approach to religion from the perspective of privacy as a reason for not bringing religion into the physician-patient communication? The secondary loop of interpretation was then to analyze whether the constructs 'the secular' and 'the non-secular' can deepen our understanding of, and approach to, existential communication in secular healthcare.

\subsection{Analytical Strategy}

The analysis went through the following four steps (Smith et al. 2009):

a. The authors read the data individually while making initial notes;

b. The authors individually extracted potential themes followed by a discussion of each case between the authors;

c. Each author then compiled the findings and checked the findings against the data material to ensure the findings were grounded in the empirical data. Disagreements where continually discussed until agreement was obtained;

d. The findings from the analysis were then discussed as a secondary loop of interpretation in relation to theory. This led to the development of the analytical constructs to enable a deeper understanding of how the informants made sense of their approach to the non-secular, still ensuring that the theoretical interpretation was grounded in the data and relevant to the research question. Derived from the secondary loop of interpretation, the final themes were established.

\subsection{Researcher Reflexivity}

As authors with a background in anthropology and religious studies (RDN) and clinical psychology of religion (AHA), we obtained our Ph.D.'s in existential communication in healthcare. Our preunderstandings stem from our Ph.D. projects interviewing physicians specialized as psychiatrists, neurologists, and in treatment of patients with chronic pain and multiple sclerosis. 


\section{Results}

Analyzing the data material and applying the secondary loop of interpretation through the analytical constructs the secular and the non-secular, we identified three themes that each represents answers as to why it is difficult to approach religion in healthcare. The themes are: (1) 'Two different spheres', (2) 'The physician's personal convictions', and (3) 'The post-secular negotiation'.

The excerpts used in the following analyses are anonymized examples representing the general understanding located in the data. All excerpts were translated from Danish to English by the authors.

\subsection{Two Different Spheres}

The theme establishes the presence of what the informants saw as two different spheres, namely that which was grounded in the secular societal discourse of healthcare and that which was not.

Excerpt 1. Health-professionally we are grounded in evidence, and that is sort of the opposite of religion.

Excerpt 2. ... I don't think you should learn it [to address religion and faith], I don't think you should wake a sleeping bear, which I think religion is. We should stick to our scientific grounding ... It's a no-go these days to talk about religion, and that is why we should go ahead with ease here ... we need to let these two things sail side by side, so to speak.

In both excerpts, the informants explain that the fundamental premise of their work as physicians is the natural scientific discourse, which is "grounded in evidence". In opposition to this is the religious discourse, which the informants explain as grounded in the opposite of evidence and as "a sleeping bear".

Analyzing the quotes through the analytical constructs deepens the understanding of the physicians' approach to the religious: They see the two discourses situated as different spheres: the secular and the non-secular. According to the informants, the non-secular is not something that they should learn to address, because they need to be true to the secular societal discourse of healthcare, which does not necessarily nor automatically include addressing the non-secular aspects of the patients. However, this leads to an uncertainty for the informant in Excerpt 2 about what to do with the non-secular, since there is no doubt that the non-secular is present (in both excerpts). The non-secular is recognized, but best left outside of the secular ("to sail side by side"), or at least to be approached with great caution, as if to avoid waking "a sleeping bear", when entering dialogue about the non-secular.

\subsection{The Physician's Personal Convictions}

Establishing that the informants are working in a cross-field between two different spheres, makes it clearer as to why it is a complicated challenge to recognize the presence of the non-secular and how one should address the non-secular in secular healthcare.

Upon analyzing the data, a further consequence of this challenge was located, namely that the informants did not address the non-secular actively unless the patients brought it up themselves. In such cases the analysis showed that the informants' personal convictions, being either a non-religious or a religious physician, influenced how they would address the non-secular aspects of their patients. However, regardless of their different personal convictions, the same uncertainty about how to address the non-secular was located.

\subsubsection{The Non-Religious Physician}

A characteristic of the non-religious informants' approach to religion was that they based their reasons for not actively addressing religion on their own non-religiosity or lack of experience with religion. Their ability to empathize with the patient and to have something to offer them in relation to the patient's religiosity seemed to depend upon the informants being religious themselves: 
Excerpt 3. Maybe I am not the best to talk about religion, because it is not something, I practice much myself.

Not being religious him/herself, the informant concludes that $\mathrm{s} /$ he should not engage in the topic and emphasizes a need to identify with religion in order address it. This understanding differs from when the physician is addressing a topic that can be contained in the secular, such as, for instance, a diagnostic aspect, where the physician's approach is not based in personal experiences with the diagnosis but in the medical education. So, why does this need to identify appear when it comes to religion as part of the non-secular sphere? Part of the answer might be found in the fact that the physicians are trained in how to address the secular aspects that patients present in consultations as part of the secular sphere. However, since the non-secular is a different sphere, the secular activities does not suffice and, consequently, the physician's experience a need to personally identify with the non-secular in order to address it.

Where the informant in Excerpt 3 does not feel equipped to talk about religion, the informant in Excerpt 4 argues the necessity of distinguishing between and separating the two spheres:

Excerpt 4.... I can empathize with a patient and tell some things about myself to show that I understand and to identify with the patient. That is not religion I know, but it would be completely over the line for me to confess to something, which I basically think is opium for the people.

The informant in Excerpt 4 is invoking empathy directly by involving personal conviction as a tool to address and understand the patient as part of building the patient-physician alliance and relationship. When confronted with religion, the informant's empathy seems to be challenged, and the informant argues that s/he would have to "confess" to something $\mathrm{s} /$ he does not identify with. Since the informant argues by quoting Marx, s/he also seems to have a negative opinion about religion. This might further challenge the informant's empathy, especially since the informant feels that s/he must identify with religion in order to address it. When identification is used as an important part of the approach to the patient, the informant is challenged, since identification with religion, as part of the non-secular, seems to compromise the boundaries of the secular sphere and the specific discourse of healthcare in which the informant is grounded as a professional, and the empathic approach of the informant reaches its limits.

This does not mean that the non-secular is a closed topic to the informants, however. It is, as mentioned above, recognized, and an open approach is stressed throughout the data, often on the understanding of meeting the patient where the patient is, with empathy as the primary professional approach, as illustrated in Excerpt 5:

Excerpt 5. I don't ask about spirituality or religion. As a person, I don't have that much to say personally about religion, but if a patient brings it up then we can talk about it ... I think that I am professional in that aspect, that I need to be able to contain and work with whatever the patient presents me with.

That the informant does not actively bring the non-secular into conversation is countered by the ambition to meet the patient where the patient is, even though the informant does not have much to offer when it comes to religion. The informant stresses the responsibility to be professional and, through this professionality, thinks that s/he should be able to be with the patient where the patient is, and "contain whatever the patient presents me with". The informant is attempting to show an openness towards the non-secular when addressing it from the secular sphere, although the informant does not have much to offer when it comes to religion.

\subsubsection{The Religious Physician}

A characteristic of the religious informants' approach to religion was that they based their reasons for not actively addressing religion on their own religiosity. In doing so, they seemed to equate their own practice of religion with a risk of proselytizing, in the sense 
that their ability to identify with religion compromised their position as professionals in secular healthcare.

Excerpt 6. I am very aware of this [being Christian] and to not influence the patients with this. I am very careful not to do this. So, I let the patient start. If they want to talk about it [religion], then I am happy to talk with them, but I am not the one who starts. ... If they ask, then I tell them that I am Christian, and we talk about it if they want. If they have another faith, then we can talk about that. I also think this is part of the alliance building, they feel they have someone to talk with about topics that may be hard to talk about in their social context.

The informant explains a carefulness when trying not to "influence the patients" with their own religiosity, leading to a reluctance to ask about religion. However, if a patient brings up religion, the informant discloses their own personal belief while focusing on the patients' faith and wants. The physician defines the secular activity as an openness toward topics that might be difficult for the patient to talk about, as a way to build the alliance. However, the physician is concerned about the risk of proselytizing but is apparently willing to leave the secular grounding and enter the non-secular sphere to further the dialogue with the patient. However, the informant stresses: only if the patient brings it up.

The informant in Excerpt 7 also voices a concern about proselytizing, while emphasizing the need to be with the patient of where the patient is:

Excerpt 7. I am religious myself, ... but I am afraid to, how can I put this, to force something on the patient. So, I can listen for what helps them, and if it helps to pray, well then support that, but I do not suggest it, that is not part of my job, because I am a physician. I have to be with people no matter where they are, and not try and move them in a specific religious direction or way to handle their religious beliefs. I think that is outside my role.

The informant is reflecting on his/her own role as a physician in the asymmetric relationship with patients to figure out how to address the non-secular in secular healthcare. To keep the professional secular approach, the informant is very aware of who is suggesting what when the topic is of a non-secular character. The informant is recognizing the potential and possibility of entering the non-secular sphere in order to be with the patient where the patient is, while conscious about the difficulties that might occur when having to navigate the non-secular through the secular activities of being a physician. These difficulties are expressed in the concern of proselytizing or moving the patient in a specific, non-secular direction.

\subsection{Employing a Post-Secular Negotiation}

The first two themes established during the analyses saw the secular and the nonsecular, founded as two different spheres, as the main reason why the informants expressed uncertainty and difficulties when addressing the non-secular in the secular sphere. Both the religious and non-religious informants expressed this uncertainty and, although from different perspectives, the result was the same: the informants did not actively address the non-secular. Through the analysis, we found a third theme, showing that, even though it was difficult for the informants to engage with the non-secular, the presence of the non-secular was recognized, and the informants tried to negotiate ways to address it while keeping their ground in the secular sphere. This came to constitute the third theme: 'the post-secular negotiation', as the attempt to interact with the non-secular in the secular sphere (here, the secular societal discourse of healthcare and related secular activities).

Excerpt 8. I had a young girl, and she was sitting very quietly the first time I met her. Then suddenly she leaned over and asked me: 'Do you believe in angels?' Then I said, 'I believe that they are real if you believe it, why do you ask?' And this was because she felt that angels were watching over her at night and she asked if I believed that and I said, 'I believe that is what you are experiencing and it sounds really nice, so you should hold on to them'. I don't think we should try to get rid of that, because that is not necessarily psychotic or anything. 
The informant takes the patient's question at face value and accepts the non-secular nature of the question. The informant accepts and appreciates the patient's positive experience with the non-secular without entering the non-secular and without explaining the metaphysical belief away or reducing it to aspects of something else. Thereby, the informant negotiates a position that can contain both spheres. Such a negotiation may help physicians to address the non-secular and, consequently, to empower the positive resources a patient potentially finds in the non-secular experience. The informant has negotiated a way to address the non-secular statements and experience of the patient without including any aspect of the informants own personal religiosity or irreligiosity and without compromising the informant as professionally grounded in the secular sphere. On the contrary, the informant negotiates from the secular discourse of healthcare, as shown in the psychiatric assessment of the belief in angels as not being psychotic.

Excerpt 9 shows a different approach with a similar result:

Excerpt 9. I have had many conversations with patients about religiosity where I in no way have mentioned my personal values, religiosity, or lack thereof. But if someone asks me then I answer honestly that I am not religious, that I don't believe in God. Sometimes in therapy this becomes productive; the way a religious patient meets me as an atheist, and this is interesting because we are all encapsulated by the way we view the world. I have experienced some good dialogues from this, without it becoming something like 'I believe in this and you are wrong'. It's more like agreeing that we have different perspectives on the world, and this open and honest approach is actually a quite important moment, very vulnerable and valuable, and gives a good relation.

The informant does not ground a conversation about religion in personal convictions. However, when confronted with the non-secular, the informant is open about the personal grounding in an irreligious understanding of the world. This is experienced as a way to create a space where the informant can talk openly, honestly, and productively with the patient about the non-secular, thereby also creating a good relationship with the patient, which the informant describes can evoke an "important moment". By being open to, and respectful of, the situational grounding of the physician and the patient in different understandings of the non-secular, the informant establishes his/her own grounding on par with the patient's in a stance of mutual respect. In this way, the informant negotiates a way to address the non-secular, not due to the professional role as physician, but to the physicians' personal convictions as an atheist, thereby establishing his/her relation to the non-secular and, through this, empowers the patient in the relevance of the nonsecular sphere.

In the physicians' approaches, focus is on the patient's needs and understandings, and although personal groundings can be expressed, there is a strive to not compromise their own professional discourse.

\section{Discussion}

Through the post-secular negotiation, the non-secular sphere is recognized as different from the secular sphere, while still approached through a secular activity (e.g., physicianpatient consultation) grounded in a secular discourse (e.g., healthcare). The discussion focuses on the post-secular negotiation, clinical implications, and research considerations.

\subsection{The Post-Secular Negotiation}

Analyzing why physicians in the current study found religion difficult to address in healthcare resulted in the recognition of two different spheres: the secular and the non-secular. The analysis thereby accentuated the theoretical point, derived from Berger, that it is not a question of whether a person is either secular or non-secular, since the two concepts refer to different spheres that people move between according to relevance. The acknowledgement of the secular and the non-secular as two distinct spheres is in accordance with research studies showing that spirituality and religion are employed by inhabitants also in countries dominated by secular discourses as approaches to the 
existential dimension, and thus are important to address in healthcare (Büssing et al. 2007; la Cour and Hvidt 2010; Pedersen et al. 2018). Thereby, a nuanced perspective is added to the understanding of human beings as not being either secular or religious/non-secular, but both secular and non-secular (Berger 2015), and furthermore, this offers a theoretical understanding for approaching the non-secular in the secular healthcare discourse.

In our findings, it was illustrated that the non-secular is present and recognized by the physicians as a possible important interaction with their patients. However, when physicians experienced patients moving between the two spheres, an ambivalent situation occurred because the physicians were uncertain about how to interact with the non-secular in secular healthcare. The situation became uncertain for the religious and irreligious physician alike, and they reached the same conclusion, namely, to approach the non-secular only if the patient brought it up and, even then, with great caution. However, if the patient can move between the two spheres while the physician has to remain in the secular sphere, this might be experienced as a barrier for communication, and the patient ends up in a position where potentially important ways of living with their illness are dissociated from their consultation and treatment. Being aware of this situation, the physicians tried to negotiate a way to approach the non-secular without compromising the secular grounding.

The post-secular negotiation as a thematic finding enabled a focus on the physicians' attempts to address the non-secular while keeping the grounding in the secular sphere. Since people hold both secular and non-secular spheres in their life, the post-secular negotiation showed an approach through which both the secular and the non-secular aspects of the patients' life could be addressed in secular healthcare through related activities. The post-secular negotiation then exemplifies the attempt to overcome the boundaries and difficulties while remaining grounded in the secular sphere. This is an argument against "balkanization" (Gonsiorek et al. 2009) in the current context, suggesting that one cannot address religion without being religious oneself. Thereby, balkanization implies a risk of creating a fragmentation in healthcare, depending on the physicians' relation to the non-secular sphere, and a risk of proselytizing one's own non-secular convictions. Instead, the post-secular negotiation between the secular and the non-secular sphere shows that the grounding is not the physician's own conviction when addressing the non-secular, but the secular grounding and competencies of healthcare. Consequently, in a secular societal discourse such as healthcare, it is possible to recognize and respect patients' non-secular convictions and experiences without proselytizing their own non-secular convictions.

The non-secular as a concept that includes all diverse approaches to the existential dimensions in life is in correspondence with current research (Andersen et al. 2021; Pedersen et al. 2018; Schnell 2011; Tarbi et al. 2021). This inclusiveness implies that religion may be less difficult to address as it becomes an aspect of the non-secular. The physicians and other health care professionals can approach the non-secular through the post-secular negotiation and listen to the patients' individual approaches to the common existential dimensions in human life. The post-secular negotiation thereby enables religion to be addressed from the professional grounding in existential communication in healthcare.

\subsection{Clinical Implications}

Healthcare is a secular societal discourse where non-secular themes are often focal points, meaning that the non-secular is inherent in healthcare; not in the secular societal discourse per se, but as a sphere inherent in the people who use the healthcare system, professional and patient alike. Seeing that the non-secular is part of the common existential conditions and that everybody is confronted with the non-secular at some point or another could support physicians when meeting the patients with empathy, not because they share the same convictions as their patients, but because they share the same common condition: the non-secular as part of being human.

As a professional representative grounded in a secular societal discourse, a precondition for breaking down the reluctance to address the non-secular may thus be a recognition of the presence of the non-secular aspects in the patients' and one's own life. Patients 
are reported to wish for a dialogue about the non-secular in relation to their illness, and some patients want to talk about these themes with their relatives or a chaplain, rather than a healthcare professional, as outlined in a review by Best et al. (2015). However, the shift between the two spheres can be almost instantaneous; a question or a comment referring to the non-secular can come 'right out of the blue', so to speak. To be prepared for addressing the non-secular, the healthcare professional can use a post-secular negotiation as an explicit reflection on how to answer ethically, respectfully, and empoweringly to any kind of non-secular comment or question from a patient. The post-secular negotiation is thus relevant because the non-secular aspects are important to patients and because the relationship between health and the non-secular is significant and influences patient health (Best et al. 2015; Koenig et al. 2012). Furthermore, the complex discussions mentioned in the introduction emphasize the context for everyday life in clinical practice as culturally complex and pluralist (Berger 2014; Nissen et al. 2021). Physicians and patients may identify with different religious orientations which may complicate addressing religion in secular healthcare even more. The post-secular negotiation offers an approach in which the potential religious diversity can be addressed.

The current study is located in the specific and different medical areas of psychiatry, chronic pain, and neurology, which might add knowledge on an overall theoretical level, as it implies a relevance for healthcare in general. Further research is needed to study the relevance of the findings related to clinical practice in other medical areas.

\subsection{Research Considerations}

The data was analyzed through the interpretative phenomenological perspective (IPA) to illuminate how the physicians in our data material made sense of their experiences with religious aspects in consultations with their patients. The further analysis was based in IPA's secondary loop of interpretation using theoretical concepts to disclose the meaning of the informants' experiences (Smith et al. 2009, p. 34). This theoretical secondary loop can be criticized for not being true to the phenomenological stance. However, throughout the analysis, we continually revisited each case to ensure the grounding in our data material while at the same time being open for new insights through exploration as a way to enhance our understanding of the phenomenon of interest (Huniche and Sørensen 2019; Johannesen 2018) as part of the iterative process that is well known in qualitative research (Maxwell 2013).

A critique of the construct of the non-secular is the negation of the secular instead of using a positive wording. Moreover, the binary construction might be viewed differently from other local contexts and countries as they can be understood as Eurocentric constructions not necessarily applicable in other contexts (Descola 2014; Mignolo 2021). However, the constructs introduced in this study are not meant to be used in everyday language but rather in analysis and theory in relation to research and current secular healthcare practice. 'The secular', 'the non-secular', and 'the post-secular negotiation' are constructs to be employed methodologically, and, as theoretical concepts, they are meant to enable a deeper understanding of, and approach to, existential communication.

The constructs further suggest a nuanced description and an enriched understanding of countries not as secular per se, but as dominated by secular societal discourses, healthcare being one such discourse, with inhabitants encompassing both the secular and the nonsecular spheres. A nuanced description, understanding, and a reformulation of what secularization means in local contexts may support existential communication in clinical practice; if the way we speak about a phenomenon does not correspond to the way people experience it, there may be a need to study possibilities for reformulations (Berger 2014). Research in other areas, such as the secular societal discourses law, education, economy, etc., might also benefit from this approach in order to study how the secular and the nonsecular interact and reciprocally influence each other and therethrough the secular societal discourses and the inhabitants. Future research could apply the proposed constructs 
in diverse secular societal discourses to test whether they can enlighten the relationship between the secular and the non-secular in other secular societal discourses than healthcare.

In relation to healthcare, it is important for further research to evaluate whether the presented understanding supports existential communication for the benefit of physicians and patients alike. This can be studied through an integration and evaluation of the differentiation between the secular and the non-secular and the practical implementation of the post-secular negotiation into education and further training.

\section{Conclusions}

The current study's employment of the constructs of 'the secular', 'the non-secular', and 'the post secular negotiation' offer a nuanced understanding of why physicians argue religion to be private and difficult to address: grounded in the secular societal discourse healthcare, the physicians were challenged in existential communication when meeting religious patients in the consultation, since religious patients employ both secular and non-secular activities and move between the two spheres according to relevance. The analysis showed that a differentiation between the secular and the non-secular opens for the non-secular to be negotiated through secular activities such as physician-patient consultations in healthcare. We conceptualize the post-secular negotiation as addressing the non-secular in a secular societal discourse through secular activities. The post-secular negotiation thereby acknowledges the continued presence of the non-secular in both society and individual and offers a way to address the non-secular without compromising the professional grounding in secular healthcare.

The current study suggests future research to understand secular countries as countries dominated by secular societal discourses and as inhabited by human beings who comprise both the secular and the non-secular spheres. This offers a nuanced understanding of existential communication in various secular societal discourses as practicing the postsecular negotiation.

The understanding of the secular, the non-secular, and the post-secular negotiation can support physicians in existential communication by emphasizing that the non-secular includes not only religion but the diversity of approaches to the existential dimensions in human life. Thereby, the post-secular negotiation presents potential for further research, for clinical practice of healthcare professionals, and, most importantly, for the benefit of patients.

Author Contributions: The authors have contributed equally to the article. All authors have read and agreed to the published version of the manuscript.

Funding: This research received no external funding.

Institutional Review Board Statement: Not applicable.

Informed Consent Statement: All involved persons (subjects or legally authorized representative) gave their informed, written consent prior to study inclusion.

Data Availability Statement: Due to anonymity reasons, no dataset will be made publicly available.

Acknowledgments: The authors thank the physicians from the participating wards, the Psychiatric Hospital Middelfart, Denmark, the Pain Management Clinic, Odense University Hospital, Denmark, and the Department of Neurology, Odense University Hospital, Denmark.

Conflicts of Interest: The authors declare no potential conflict of interest.

\section{References}

Agledahl, Kari Milch, Pål Gulbrandsen, Reidun Førde, and Åge Wifstad. 2011. Courteous but not curious: How doctors' politeness masks their existential neglect. A qualitative study of video-recorded patient consultations. Journal of Medical Ethics 37: 650-54. [CrossRef] [PubMed]

Anandarajah, Gowri, Janet Roseman, Leela G. Mennillo, and Brendan Kelley. 2021. Spirituality in primary palliative care and beyond: A 20-year longitudinal qualitative study of interacting factors impacting physicians' spiritual care provision over time. Journal of Pain and Symptom Management 62: 1216-28. [CrossRef] [PubMed] 
Andersen, Aida Hougaard. 2020. Physicians' Communication about Existential, Spiritual and Religious Needs with Patients Living with Chronic Pain or Multiple Sclerosis: Conversation or Nonversation? Ph.D. thesis, University of Southern Denmark, Odense, Denmark.

Andersen, Aida Hougaard, Elisabeth Assing Hvidt, Niels Christian Hvidt, and Kirsten Kaya Roessler. 2019a. Doctor-patient communication about existential, spiritual and religious needs in chronic pain: A systematic review. Archive for the Psychology of Religion 23. [CrossRef]

Andersen, Aida Hougaard, Elisabeth Assing Hvidt, Niels Christian Hvidt, Zsolt Illés, Gitte Handberg, and Kirsten Kaya Roessler. 2019b. Conversation or non-versation? Physicians' communication about existential, spiritual and religious needs with chronically ill patients—Protocol for a qualitative study. European Journal for Person Centered Healthcare 7: 9.

Andersen, Aida Hougaard, Elisabeth Assing Hvidt, Niels Christian Hvidt, and Kirsten Kaya Roessler. 2020. 'Maybe we are losing sight of the human dimension'-Physicians' approaches to existential, spiritual, and religious needs among patients with chronic pain or multiple sclerosis. A qualitative interview-study. Health Psychology and Behavioral Medicine 8: 248-69. [CrossRef]

Andersen, Aida Hougaard, Elisabeth Assing Hvidt, Lotte Huniche, Niels Christian Hvidt, and Kirsten Kaya Roessler. 2021. Why We Suffer? Existential Challenges of Patients with Chronic Illness: A Kierkegaardian Inspired Interpretative Phenomenological Analysis. Journal of Humanistic Psychology. [CrossRef]

Assing Hvidt, Elisabeth, Jens Søndergaard, Dorte Gilså Hansen, Pål Gulbrandsen, Jette Ammentorp, Connie Timmermann, and Niels Christian Hvidt. 2017. 'We are the barriers': Danish general practitioners' interpretations of why the existential and spiritual dimensions are neglected in patient care. Communication $\mathcal{E}$ Medicine 14: 108-20. [CrossRef]

Beaumont, Justin, Klaus Eder, and Eduardo Mendieta. 2020. Reflexive secularization? Concepts, processes and antagonisms of postsecularity. European Journal of Social Theory 23: 291-309. [CrossRef]

Beckford, James A. 2003. Social Theory and Religion. Cambridge: Cambridge University Press. [CrossRef]

Berger, Peter L. 1999. The Desecularization of the World: Resurgent Religion and World Politics. Michigan: Wm. B. Eerdmans Publishing. ISBN 9780802846914.

Berger, Peter L. 2014. The Many Altars of Modernity. Boston and Berlin: De Gruyter. [CrossRef]

Berger, Peter L. 2015. The Hospital: On the Interface Between Secularity and Religion. Society 52: 410-12. [CrossRef]

Berger, Peeter L., and Thomas Luckmann. 2016. Den Sociale Konstruktion af Virkeligheden-En Vidensociologisk Afhandling. Copenhagen: Akademisk Forlag. ISBN 9788750038306.

Best, Megan, Phyllis Butow, and Ian Olver. 2015. Do patients want doctors to talk about spirituality? A systematic literature review. Patient Education and Counseling 98: 1320-28. [CrossRef] [PubMed]

Best, Megan, Phyllis Butow, and Ian Olver. 2016. Doctors discussing religion and spirituality: A systematic literature review. Palliative Medicine 30: 327-37. [CrossRef]

Breemer, Rosemarie Van Den, Jose Casanova, and Trygve Wyller. 2014. Secular and Sacred: The Scandinavian Case of Religion in Human Rights, Law and Public Space. Göttingen: Vandenhoeck \& Ruprecht GMBH \& Co. KG, Bristol: Vandehoeck \& Ruprecht LLC. ISBN 978-3-525-60449-6.

Brémault-Phillips, Suzette, Joanne Olson, Pamela Brett-MacLean, Doreen Oneschuk, Shane Sinclair, Ralph Magnus, Jeanne Weis, Marjan Abbasi, Jasneet Parmar, and Christina M. Puchalski. 2015. Integrating Spirituality as a Key Component of Patient Care. Religions 6: 476. [CrossRef]

Büssing, Arndt, Thomas Ostermann, and Harold G. Koenig. 2007. Relevance of religion and spirituality in German patients with chronic diseases. International Journal of Psychiatry in Medicine 37: 39-57. [CrossRef]

Carr, Tracy Jean. 2010. Facing Existential Realities: Exploring Barriers and Challenges to Spiritual Nursing Care. Qualitative Health Research 20: 1379-92. [CrossRef] [PubMed]

Damberg Nissen, Ricko, Frederik Gildberg, and Niels Christian Hvidt. 2018. Psychiatry, a Secular Discipline in a Postsecular World? A Review. Religions 9: 32. [CrossRef]

DeMarinis, Valerie. 2008. The Impact of Postmodernization on Existential Health in Sweden: Psychology of Religion's Function in Existential Public Health Analysis. Archive for the Psychology of Religion 30: 57-74. [CrossRef]

Descola, Philippe. 2014. Beyond Nature and Culture. Chicago: University of Chicago Press.

Dillard, Victoria, Julia Moss, Natalie Padgett, Xiyan Tan, and Ann Blair Kennedy. 2021. Attitudes, beliefs and behaviors of religiosity, spirituality, and cultural competence in the medical profession: A cross-sectional survey study. PLoS ONE 16: e0252750. [CrossRef] [PubMed]

Eder, Klaus, and Giancarlo Bosetti. 2006. Post-secularism: A return to the public sphere. Eurozine 8: 17-20.

Eisenstadt, Schmuel N. 2000. Multiple Modernities. Daedalus 129: 1-29.

Gonsiorek, John C., P. Scott Richards, Kenneth I. Pargament, and Mark R. McMinn. 2009. Ethical challenges and opportunities at the edge: Incorporating spirituality and religion into psychotherapy. Professional Psychology: Research and Practice 40: 385-95. [CrossRef]

Gorski, Philip S., David Kyuman Kim, John Torpey, and Jonathan Van Antwerpen. 2012. The Post-Secular in Question: Religion in Contemporary Society. New York: NYU Press, Available online: http:/ /www.jstor.org/stable/j.ctt9qfmzz (accessed on 14 December 2021).

Granqvist, Pehr. 2020. Attachment in Religion and Spirituality. A Wider View. New York: The Guilford Press. 
Gulbrandsen, Pål, Marla L. Clayman, Mary Catherine Beach, Paul K. Han, Emily F. Boss, Eirik H. Ofstad, and Glyn Elwyn. 2016. Shared decision-making as an existential journey: Aiming for restored autonomous capacity. Patient Education and Counseling 99: 1505-10. [CrossRef]

Habermas, Jurgen. 2008. Notes on Post-Secular Society. New Perspectives Quarterly 25: 17-29. [CrossRef]

Hodkinson, James, and Silke Horstkotte. 2020. Introducing the Postsecular: From Conceptual Beginnings to Cultural Theory. Poetics Today 41: 317-26. [CrossRef]

Huniche, Lotte, and Estrid Sørensen. 2019. Phenomenon-driven research and systematic research assembling: Methodological conceptualisations for psychology's epistemic projects. Theory E Psychology 29: 539-58. [CrossRef]

Johannesen, Helle. 2018. På sporet af sammenhænge. In Kvalitative Analysemetoder i Sundhedsforskning. Edited by Gildberg Frederik Alkier and Hounsgaard Lise. Aarhus: Klim.

Koenig, Harold G., Michael E. McCullough, and David B. Larson. 2001. Handbook of Religion and Health, 1st ed. Oxford: Oxford University Press.

Koenig, Harold G., Dana E. King, and Verna Benner Carson. 2012. Handbook of Religion and Health, 2nd ed. Oxford: Oxford University Press.

Köhrsen, Jens. 2012. How religious is the public sphere? A critical stance on the debate about public religion and post-secularity. Acta Sociologica 55: 273-88. [CrossRef]

Kørup, Alex, Jens Søndergaard, Nada Alyousefi, Giancarlo Lucchetti, Klaus Baumann, Eunmi Lee, Azimatul Karimah, Parameshwaran Ramakrishnan, Eckhard Frick, Arndt Büssing, and et al. 2021. Health professionals' attitudes toward religiosity and spirituality: A NERSH Data Pool based on 23 surveys from six continents. F1000Research 10: 446. [CrossRef]

la Cour, Peter, and Niels Christian Hvidt. 2010. Research on meaning-making and health in secular society: Secular, spiritual and religious existential orientations. Social Science \& Medicine 71: 1292-99. [CrossRef]

Maxwell, Joseph A. 2013. Qualitative Research Design: An Interactive Approach, 3rd ed. Thousand Oaks: SAGE Publications, vol. 41.

Mignolo, Walter D. 2021. The Politics of Decolonial Investigations. Durham: Duke University Press.

Nissen, Ricko. 2019. In That Most Secular of Rooms-The Religious Patient in Secular Psychiatry. Ph.D. thesis, University of Southern Denmark, Odense, Denmark.

Nissen, Ricko Damberg, Frederik A. Gildberg, and Niels Christian Hvidt. 2019a. Approaching the religious patient in forensic psychiatry, with special focus on ethnic minority patients. Mental Health, Religion \& Culture 22: 694-710. [CrossRef]

Nissen, Ricko Damberg, Frederik A. Gildberg, and Niels Christian Hvidt. 2019b. Approaching the religious psychiatric patient in a secular country: Does "subalternalizing" religious patients mean they do not exist? Archive for the Psychology of Religion 41: 123-40. [CrossRef]

Nissen, Ricko Damberg, Dorte Toudal Viftrup, and Niels Christian Hvidt. 2021. The Process of Spiritual Care. Front. Psychol. 12 : 674453. [CrossRef]

Nynäs, Peter, Mika Lassander, and Terhi Utriainen. 2021. Post-Secular Society. Edited by Peter Nynäs, Mika Lassander and Terhi Utriainen. New York: Routledge. [CrossRef]

Pargament, Kenneth I., Doug Oman, Julie Pomerleau, and Annette Mahoney. 2017. Some Contributions of a Psychological Approach to the Study of the Sacred. Religion 47: 718-44. [CrossRef]

Pedersen, Heidi Frølund, Marit Handegard Birkeland, Jens Søndergaard Jensen, Tatjana Schnell, Niels Christian Hvidt, Torgeir Sørensen, and Peter la Cour. 2018. What brings meaning to life in a highly secular society? A study on sources of meaning among Danes. Scandinavian Journal of Psychology 59: 678-90. [CrossRef]

Perrin, Joël, Nina Streeck, Rahel Naef, Michael Rufer, Simon Peng-Keller, and Horst Rettke. 2021. Comparing perspectives: Patients' and health care professionals' views on spiritual concerns and needs in chronic pain care-A qualitative study. BMC Health Services Research 21: 504. [CrossRef] [PubMed]

Possamai, Adam. 2017. Post-secularism in multiple modernities. Journal of Sociology 53: 822-35. [CrossRef]

Puchalski, Christina M., Robert Vitillo, Sharon K. Hull, and Nancy Reller. 2014. Improving the spiritual dimension of whole person care: Reaching national and international consensus. Journal of Palliative Medicine 17: 642-56. [CrossRef] [PubMed]

Schnell, Tatjana. 2011. Individual differences in meaning-making: Considering the variety of sources of meaning, their density and diversity. Personality and Individual Differences 51: 667-73. [CrossRef]

Sloan, Richard P., Emilia Bagiella, and Tia Powell. 1999. Religion, spirituality, and medicine. The Lancet 353: 664-67. [CrossRef]

Smith, Jonathan A., Paul Flowers, and Michael Larkin. 2009. Interpretative Phenomenological Analysis: Theory, Method and Research. London, California, New Dehli and Singapore: SAGE.

Stark, Rodney. 1999. Secularization, R.I.P. Sociology of Religion 60: 249-73. [CrossRef]

Stolz, Jörg. 2020. Secularization theories in the twenty-first century: Ideas, evidence, and problems. Presidential address. Social Compass 67: 282-308. [CrossRef]

Søberg, Ane Inger Bondahl, Sigrid Helene Kjørven Haug, Lars Johan Danbolt, Lars Lien, and Torgeir Sørensen. 2018. Existential themes in the treatment of people at suicide risk. Understandings and practices of specialist healthcare professionals. Mental Health, Religion E Culture 21: 588-600. [CrossRef]

Sørensen, Torgeir, Peter la Cour, Lars Johan Danbolt, Hans Stifoss-Hanssen, Lars Lien, Valerie DeMarinis, Heidi Frølund Pedersen, and Tatjana Schnell. 2019. The Sources of Meaning and Meaning in Life Questionnaire in the Norwegian context: Relations to mental health, quality of life, and self-efficacy. The International Journal for the Psychology of Religion 29: 32-45. [CrossRef] 
Tarbi, Elise C., Robert Gramling, Christine Bradway, and Salimah H. Meghani. 2021. "If it's the time, it's the time": Existential communication in naturally-occurring palliative care conversations with individuals with advanced cancer, their families, and clinicians. Patient Education and Counseling 104: 2963-68. [CrossRef] [PubMed]

Taylor, Charles. 2007. A Secular Age. Cambridge: The Belknap Press of Harvard University Press.

Thomas, Dylan. 2017. The Poems of Dylan Thomas. New York: New Directions Publishing Corporation.

Wohlrab-Sahr, Monika, and Marian Burchardt. 2012. Multiple Secularities: Toward a Cultural Sociology of Secular Modernities. Comparative Sociology 11: 875-909. [CrossRef]

Zuckerman, Phil. 2008. Society without God. What the Least Religious Nations Can Tell Us about Contentment. New York and London: NYU Press. 